\title{
A Comparative Study of Green Synthesized AgNPs using Carissa Carandas and Nerium indicum Leaves and its Activities against Selected Human Pathogens and MCF 7 Cell
}

\author{
Prabhakara Rao Dasari ${ }^{1, * *}$, Sofia Pilli², Ravi Jon ${ }^{3}$ \\ ${ }^{1}$ Department of Chemistry, Sam Higginbottom University of Agriculture, Technology \& Sciences, Prayagraj 211007, India \\ 2Department of Biotechnology, Indian Institute of Technology, Roorkee, Uttarakhand, India \\ ${ }^{3}$ Department of Physics, Sam Higginbottom University of Agriculture, Technology \& Sciences, Prayagraj 211007, India
}

*Corresponding author: E-mail: prabhakararao1986@gmail.com

DOI: 10.5185/amlett.2020.111576

The present work reports an ecofriendly method for biosynthesis of AgNPs using an aqueous leaves extracts of Carissa carandas and Nerium indicum plants. These extracts play a significant role for the formation of AgNPs. The obtained AgNPs were characterized by Ultraviolet-Visible Spectrophotometry. The UVspectrum showed that the absorbance peak at $440 \mathrm{~nm}$. TEM analysis shown morphology and crystalline of nanoparticles as 20 and $40 \mathrm{~nm}$ sizes and spherical shape. The SEM and EDXA analysis was shown identify elemental composition and confirm the NPs of desired elements. The FTIR analysis showed functional group elements as amide, hydroxyl and amino groups in NPs. These results were confirming the AgNPs have been best activity against human pathogens. The AgNPs showed high potential antibacterial activity toward the selected pathogenic bacteria. Therefore, Carissa carandas and Nerium indicum leaves aqueous extract AgNPs can provide application in future development as nano-medicine, nanotechnology as antifungal activity on Aspergillus niger and candida albicans and then anticancer activity on MCF-7 cell line. Finally, the Nerium indicum leaves aqueous extract AgNPs were more effective in antibacterial, antifungal and anticancer activity than Carissa carandas AgNPs.

\section{Introduction}

Globally many techniques are well developed and documented for the research in every stream as engineering, sciences, medicine, pharmaceutical and synthesis of metal nanoparticles. Some of the techniques like nanotechnology, biotechnology and biosynthesis of nanoparticles should be developed in the environmentally friendly technique in the material synthesis [1]. During recent years, AgNPs have been growing fast due to the unique characteristics and importance in antibacterial, biological, catalytic, chemical, electronic, electrochemical, optical and photo-magnetic properties [2]. The silver and gold NPs attracted researchers because of their unique applications in field like agriculture, drug delivery systems, food sectors, biomedical field, textile units and water treatment $[3,4]$.

The use of micro-organisms as antimicrobial, antifungal agent and as a catalyst for synthesis of nanoparticles and nanometals were explored. Sastry and Co-workers studied about the use of plant materials and microbes as nanofactories [5-7]. Synthesis of nanoparticles obtained by chemical and physical methods are environment friendly. This also includes design development by renewable high energy efficient nanomaterials. The biological method developed for synthesis of AgNPs are very important in the field of nanotechnology evolving synthesis of nanoparticles as nanomaterials $[\mathbf{8 , 9}]$.

The nanomaterials production from different plant parts are used in wide range antimicrobial activities. Various plants parts like leaves, fruits and seeds have used for the reduction of zinc, copper, gold, platinum, silver and titanium NPs in many shapes and sizes, and they are well documented. For synthesis of NPs of controlled size and shapes, various methods have been used. The synthesis of AgNPs using bacteria, fungi, cyanobacteria and biomolecules of various plant materials have been reported [10-12]. Recently different parts of the plant fruits had been studied as resuming and capping extracts like bark, fruit, callus, fruit peels and root [13].

In this present work an attempt was made to biosynthesize AgNPs by silver nitrate reduction process using extracts of leaves and stem of Carissa carandas (CC) and Nerium indicum (NI) plant. These plants are used as medicines, ayurvedic ointments as condiments and to enhance flavoring in cooking and preparation of icecreams, desserts, spicy candies, chocolate, tea, hot cocoa and liquors etc. In medicinal field, it is used to treat diarrhea, colds and other problems of digestive system. $\mathrm{CC}$ and NI leaves extract is environment friendly, nontoxic and reduce blood glucose, inflammation, lipid levels 


\section{Advanced Materials Letters www.vbripress.com/aml}

and raise serum insulin levels and act as reducing and capping agent for bio-reduction of silver nitrate. Additionally, the antibacterial activity of these biosynthesized AgNPs was examined. The AgNPs maintain the effective role of antimicrobial activity. These all things depend upon the unique properties of nanoparticles. Many nanoparticles used for treatment of the various types of diseases and it require more detailed investigation in the field of toxicity [14-16].

\section{Material and methods}

All chemicals used were of analytical grade reagents. $\mathrm{AgNO}_{3}$, deionized water and sodium chloride. Fresh, healthy leaves of Carissa carandas (CC) and Nerium indicum (NI) were collected from horticulture department, SHUATS, Allahabad, India. The collected leaves and stem of CC and NN as shown in Fig. 1(a)(b). 3 grams of stored fine leaves powder was mixed with $100 \mathrm{ml}$ of deionized water separately in two $500 \mathrm{ml}$ conical flasks with the help of glass-rod, and boiled for $10 \mathrm{~min}$ at $100^{\circ} \mathrm{C}$. It was cooled and filtered by Whatman filter paper No.1. $80 \mathrm{ml}$ of this aqueous extract was collected and stored in refrigerator at $4^{\circ} \mathrm{C}$ for further studies as shown in Fig. 1(c)(d).
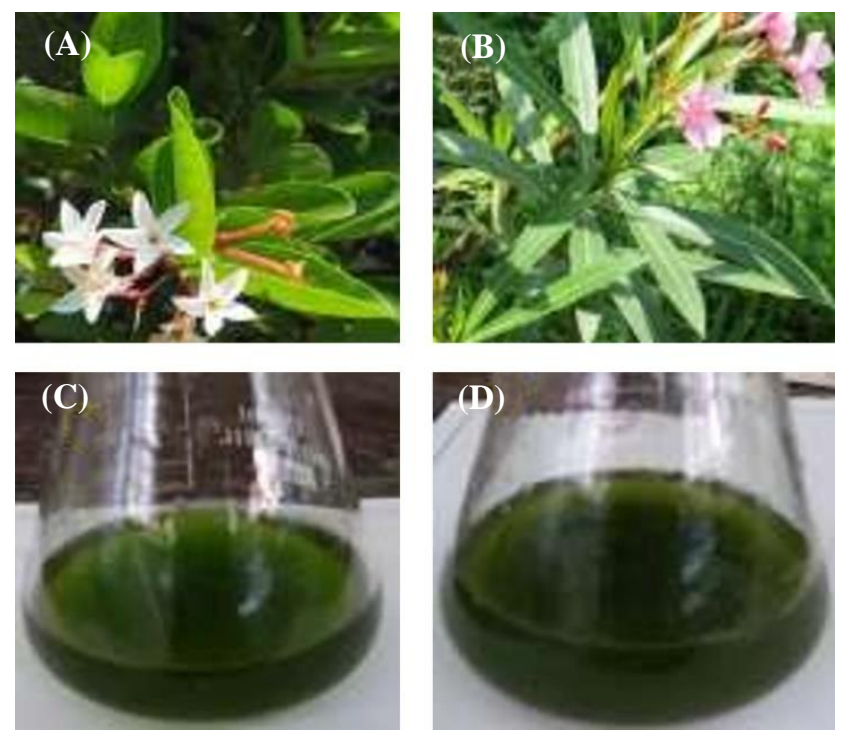

Fig. 1. Image of Carissa carandas leaves (A) and Extract (C), Nerium indicum leaves (B) and Extract (D).

\section{Synthesis of silver nanoparticles}

$10 \mathrm{~mL}$ each of above prepared extract solution of CC and NI leaves were mixed drop wise with $90 \mathrm{~mL}$ of freshly prepared $10^{3} \mathrm{mM} \mathrm{AgNO}$ solution. The flasks were stirred vigorously with the help of magnetic stirrer, till the silver nitrate solution mixed with extract. Change of colour from light yellow to dark brown indicates the formation of AgNPs as shown in Fig. 2(a)(b). After formation, the solutions were washed with deionized water and centrifuged at $1000 \mathrm{rpm}$ for $30 \mathrm{~min}$ and the final product of CC and NI leaves was collected for further characterization [17].
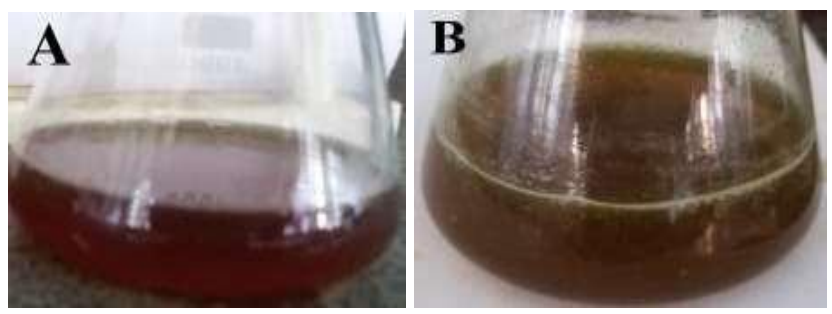

C

UV-VISBLE SPECTROSCOPY

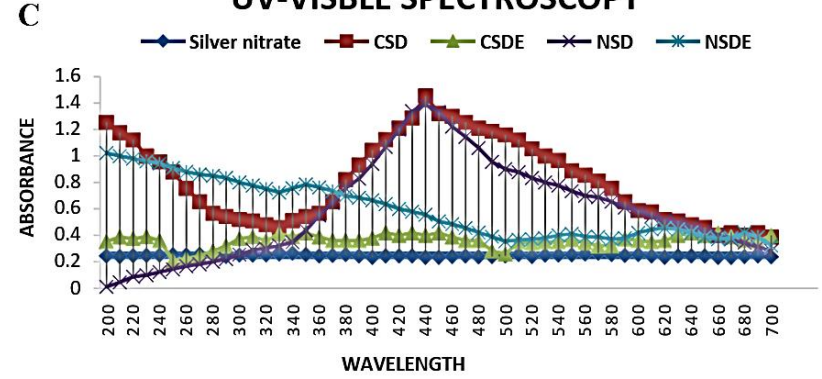

Fig. 2. Image of Carissa carandas (A) and Nerium indicum (B) nanoparticle, these nanoparticles showed peaks in UV-Vis spectroscopy analysis graph (C).

\section{Characterization techniques}

The synthesized AgNPs were characterized by different techniques. The Ultra Violet absorption spectra were recorded UV-Visible spectroscopy (Global instruments, UV-5100) (32-34), identification of functional groups by FTIR (Model JASCO FT-IR-5300, Perkin-Elmer) (37), TEM analysis (Model EM-410 LS, Philips, Holland), Surface morphology was carried out with SEM-EDX (JSM 6510LV, Perkin Elmer).

\section{Bacterial culture organism and maintenance}

The bacterial strains cultured in nutrient broth medium to develop bacterial growth in microbiological lab. The Gram-positive bacteria such as Bacillus cereus, Staphylococcus aureus and gram-negative bacteria Escherichia coli, Klebsiella pneumonia and Pseudomonas aeruginosa had been obtained from culture bank of microbiology department, SHUATS.

The fungal strains viz, Aspergillus niger and Candida albicans were used for antifungal activity $[\mathbf{1 8 , 1 9 ]}$. These fungal strains were collected from Department of Microbiology and Fermentation Technology, SHUATS, Allahabad, India. These fungal strains were grown and maintained on the potato dextrose agar slants at $27^{\circ} \mathrm{C} \pm$ $0.5^{\circ} \mathrm{C}$. Fluconazole was used as standard, and was dissolved $(1 \mathrm{mg} / \mathrm{mL})$ in DMSO solvent. The NPs were evaluated for the antifungal activity against the selected fungal strains by agar and the overtures to adopt according to $[\mathbf{2 0 , 2 1 ]}$.

The AgNPs synthesized from leaf extracts of Carissa carandas and Nerium indicum were tested for anti- cancer activity on breast adenocarcinoma (MCF-7) cell in different concentrations. The anticancer screening was done by Sulforhodamine B (SRB) calorimetric assay according to procedure of Skehan et al., (1990) and Vanicha \& kirtitikara (2006) research papers [22-24]. The anti-Cancer 


\section{Advanced Materials Letters www.vbripress.com/aml}

activity was done at Tata Memorial Centre, Advanced Centre for Treatment, Research and Education in Cancer (ACTREC). Percent growth calculated on the plate-byplate basis for these test wells about control wells. Percentage growing on the reserve was intended as: [Ti / C] x $100 \%$.

\section{Results and discussion}

The AgNPs obtained from CC and NI leaves aqueous extract shows the reduction of ionic strength of silver ions in both samples by visual observations. The samples turned from yellow to dark brown and greenish to dark brown in $2 \mathrm{~h}$. The synthesized nanoparticles were more stable due to rate of silver ions conversion to AgNPs. The color change was confirmed by the formation of AgNPs due to the colloidal solution contains biomolecules in the extract. The absorption spectrum depends on the shape and size of nanoparticles.

The color change samples solution was observed by UV-Vis spectroscopy. In Fig. 2(c), the metallic AgNPs showed the well-defined strong absorption peak at $440 \mathrm{~nm}$ for CC and NI leaves extract. The formation of absorption peaks was observed in intensity energy order state. The band intensity indicates the small size, spherical shaped NPs.

In the Fig. 3(a)(b), the morphology size and shape of AgNPs of CC and NI leaves were observed by TEM.The TEM image of CC AgNPs showed non-uniform size as 12 to $15 \mathrm{~nm}$, shapes such as circular, spherical, rod and diamond shapes. The NI AgNPs were in the rang from 14 to $26 \mathrm{~nm}$. These nanoparticles were well dispersed at $1,00,000$ magnification range at $\mathrm{HV}-200.0 \mathrm{Kv}$. These nanoparticles were more stable.
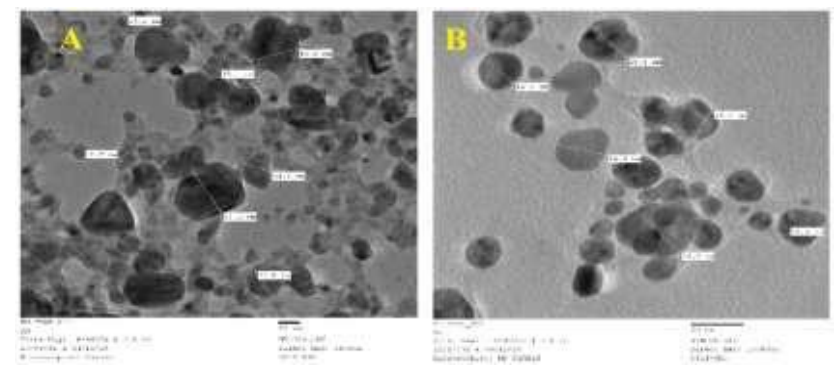

Fig. 3. Image of Carissa carandas and Nerium indicum TEM synthesized of AgNPs Leaves.

Scanning Electron Microscope (SEM) was used to understand the surface morphology of AgNPs synthesized from CC and NI as shown in Fig. 4(a)(b). The size of the synthesized AgNPs of CC is $40 \mathrm{~nm}$ and NI as $40 \mathrm{~nm}$ by SEM analysis at $8000 \mathrm{x}$ magnification range. The observed nanoparticles were not dispersed effectively due to the colloidal solution and the formation of nanoclusters. The image of SEM showed the circular, rod and spherical shape of nanoparticles with a diameter range of $1 \mu \mathrm{m}$ of various nanoparticles. In this image AgNPs were variations in the particle size, microstructure and clusters because of aggregation and evaporation of solvent during sample preparation.
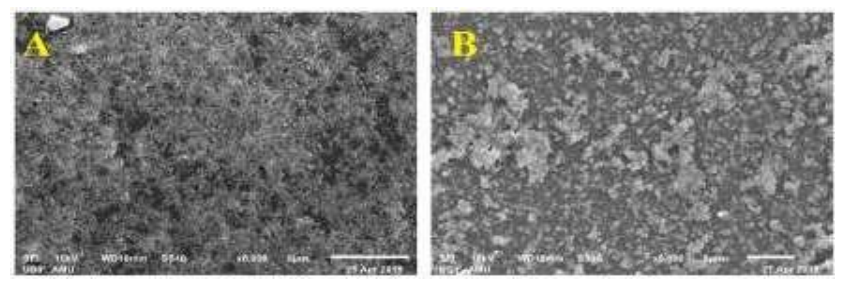

Fig. 4. SEM images of Carissa carandas and Nerium indicum AgNPs of leaves.

The EDX analysis was observed for the AgNPs strong peaks of CC and NI leaves extract was recorded. The metallic NPs shows typical absorption peaks were approximately at 1.8 to $2.9 \mathrm{keV}$. In the presence of $\mathrm{CC}$ and NI leaves extract AgNPs showed broad signals and other signals were also present such as oxygen, sodium, potassium and titanium due to long signal. The EDX spectrum revealed strong signals in the Ag region and five different areas for two samples and thus confirmed the formation of silver nanoparticles. Fig. 5 (a)(b) shows the impurities AgNPs of CC and NI leaves obtained by EDX. It has been verified that the shape, size, solubility, surface area, dispersion factor and chemical composition of nanoparticles play an exceptional role in the determining their biological activities.

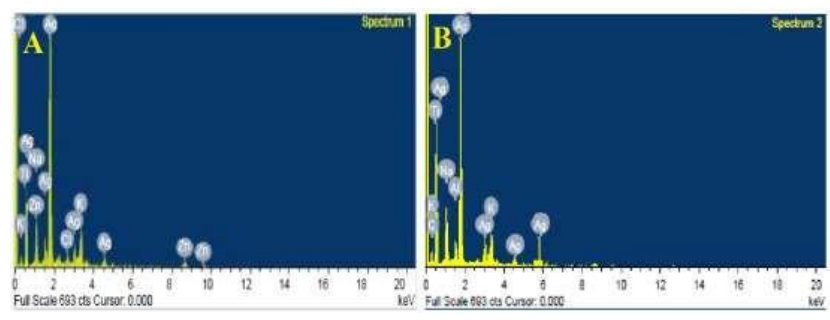

Fig. 5. Image of EDAX spectrum of AgNPs of Carissa carandas and Nerium indicum leaves.

The FT-IR analysis is an important tool which is used to identify the functional groups of the metal nanoparticles and biomolecules present in the AgNPs of $\mathrm{CC}$ and NI leaves extract. In this present study, FT-IR analysis showed, the identified biomolecules responsible for capping and stabilizing silver nanoparticles.
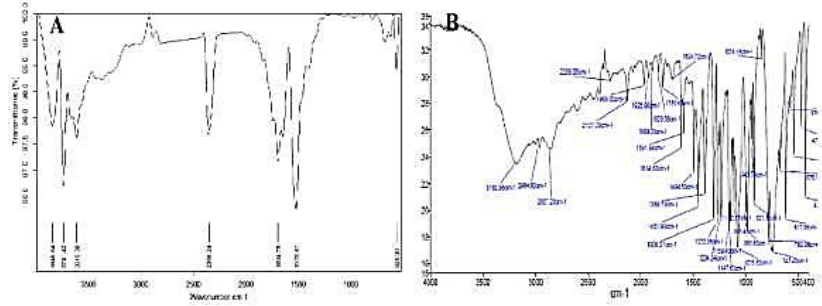

Fig. 6. FTIR spectrum of Carissa carandas (A) and Nerium indicum (B) of AgNPs.

Fig. 6(a)(b) shows different peaks at $3846.64 \mathrm{~cm}^{-1}$, $3741.42 \mathrm{~cm}^{-1}, 3615.39 \mathrm{~cm}^{-1}, 2356.24 \mathrm{~cm}^{-1}, 1694.75 \mathrm{~cm}^{-1}$, $1523.47 \mathrm{~cm}^{-1}$ and $564.38 \mathrm{~cm}^{-1}$ and NI aqueous extract AgNPs showed the two prominent bands at $3355.14 \mathrm{~cm}^{-1}$ and $1685.28 \mathrm{~cm}^{-1}$. These functional groups play an important role in synthesis of AgNPs. The functional 


\section{Advanced Materials Letters www.vbripress.com/aml}

groups of NPs in $3615.39 \mathrm{~cm}^{-1}$ and $3741.42 \mathrm{~cm}^{-1}$ were bands showing $\mathrm{OH}$ group biomolecules and $2356.24 \mathrm{~cm}^{-1}$ showed Si-H silane (stretching), $1694.75 \mathrm{~cm}^{-1}$ showed $(\mathrm{C}=\mathrm{O})$ at amide present in $\mathrm{I}^{\text {st }}$ band. The $1523.47 \mathrm{~cm}^{-1}$ observed the stretching because of $\mathrm{N}-\mathrm{H}$ amide group in II ${ }^{\text {nd }}$ band [38].

\section{Antibacterial activity}

The biologically synthesized AgNPs from different parts such as leaves of CC and NI plant showed the excellent antibacterial activity against selected human pathogens. The AgNPs of CC and NI leaves extract are tested with control of antibiotic Ciprofloxacin, silver nitrate and extracts of plant parts. $100 \mu \mathrm{l}$ of AgNPs as taken compared with control samples of $\mathrm{AgNO}_{3}$, plant extracts and Ciprofloxacin drug according to standard procedure, suspension solution in four well of petri dish plates. Various selected human pathogenic strains had been reported to possess the different inhibitory zone effect towards AgNPs. The four replicates and its diameter was measured in mm (millimeter) and tabulated along with mean inhibitory zone of antibacterial activity. It was observed that silver ions can act as strong antibacterial agent. The membrane structure of bacteria changed because diffusion of metal ions lead to the enlarged membrane permeability of the bacteria $[\mathbf{2 5}, \mathbf{2 6}, \mathbf{3 9}]$. Fig. 7(a)(b) photographs taken after $24 \mathrm{hrs}$. with visible zone of inhibition (ZOI), showing the antibacterial activity against positive bacteria Bacillus cereus, Salamenella aureus and negative bacterial sps such as Escherichia coli, Klebsiella pneumonia and Pseudomonas aeruginosa bacteria.

The AgNPs of Carissa carandas and Nerium indicum leaves showed excellent inhibition zone in case of positive bacteria Bacillus cereus than Escherichia Coli and Salamenella Aureus as well as when compared to the other control sample of Ciprofloxacin drug, silver nitrate and plant extract also. The Carissa carandas and Nerium indicum stem AgNPs were showed in Table 1 (A \& B), good inhibition zone gram positive bacteria

Bacillus cereus as Carissa carandas and Nerium indicum leaves AgNPs than Escherichia Coli and Salamenella Aureus. And the Carissa carandas and Nerium indicum leaves AgNPs good inhibition zone showed in gram negative bacteria's Sedomonas Aeroginosa was inhibition zone than Eeficalic Facilic bacterial and in stem AgNPs were showed effective inhibition zone Eeficalic Facilic than Sedomonas Aeroginosa opposite of leaves AgNPs of $\mathrm{CC}$ and NI. Finally, when we compare the AgNPs inhibition zone was very effective on all control samples as Ciprofloxacin, silver nitrate and extracts at the same concentration of all samples $[\mathbf{2 7}, \mathbf{2 8 , 2 , 2 9}]$.

Table 1(A). Effect of AgNPs of Carissa carandas leaf extract on different antimicrobial, Zone of diameter in $\mathrm{mm}$ (mean of four replicates)

\begin{tabular}{lcccc}
\hline $\begin{array}{l}\text { Micro } \\
\text { organisms }\end{array}$ & $\begin{array}{c}\text { Nanoparticles } \\
(\mathbf{N}) \mathbf{~ m m}\end{array}$ & AgNO3 (A) mm & $\begin{array}{c}\text { Standard (S) } \\
\mathbf{~ m m}\end{array}$ & Extract \\
\hline $\begin{array}{l}\text { Escherichia } \\
\text { coli }(-)\end{array}$ & $14.100 \pm 0.100 \mathrm{e}$ & $11.167 \pm 0.153$ & $18.100 \pm 0.100$ & 0 \\
$\begin{array}{l}\text { Klebsiella } \\
\text { pneumonia (-) }\end{array}$ & $16.100 \pm 0.100 \mathrm{a}$ & $15.300 \pm 0.200$ & $20.133 \pm 0.153$ & 0 \\
$\begin{array}{l}\text { Pseudomonas } \\
\text { aeruginosa (-) } \\
\text { Bacillus cereus }\end{array}$ & $15.100 \pm 0.100 \mathrm{c}$ & $11.900 \pm 0.608$ & $17.000 \pm 1.300$ & 0 \\
$\begin{array}{l}+) \\
\text { Staphylococcus }\end{array}$ & $14.133 \pm 0.153 \mathrm{~d}$ & $11.100 \pm 0.100$ & $11.567 \pm 0.153$ & 0 \\
\begin{tabular}{l} 
Aureus $(+)$ \\
\hline
\end{tabular} & & $13.133 \pm 0.153$ & $19.133 \pm 0.153$ & 0 \\
\hline
\end{tabular}

Table 1(B). Effect of AgNPs of Nerium indicum leaf extract on different antimicrobial, Zone of diameter in $\mathrm{mm}$ (mean of four replicates).

\begin{tabular}{lcccc}
\hline $\begin{array}{l}\text { Micro } \\
\text { organisms }\end{array}$ & Nanoparticles & AgNO3 & Standard & Extract \\
\hline $\begin{array}{l}\text { Escherichia } \\
\text { coli (-) }\end{array}$ & $16.167 \pm 0.153 \mathrm{~d}$ & $10.133 \pm 0.115$ & $17.200 \pm 0.265 \mathrm{c}$ & 0 \\
$\begin{array}{l}\text { Klebsiella } \\
\text { Pneumonia (-) }\end{array}$ & $16.200 \pm 0.346 \mathrm{c}$ & $14.233 \pm 0.153$ & $20.100 \pm 0.100 \mathrm{a}$ & 0 \\
$\begin{array}{l}\text { Pseudomonas } \\
\text { Aeruginosa (-) }\end{array}$ & $15.267 \pm 0.252 \mathrm{e}$ & $12.533 \pm 0.058$ & $18.167 \pm 0.208 \mathrm{~b}$ & 0 \\
$\begin{array}{l}\text { Bacillus } \\
\text { cereus(+) }\end{array}$ & $18.200 \pm 0.200 \mathrm{a}$ & $13.200 \pm 0.200$ & $20.100 \pm 0.100 \mathrm{a}$ & 0 \\
$\begin{array}{l}\text { Staphylococcus } \\
\text { Aureus }(+)\end{array}$ & $18.167 \pm 0.153 \mathrm{~b}$ & $14.367 \pm 0.153$ & $13.233 \pm 0.252 \mathrm{~d}$ & 0 \\
\hline
\end{tabular}
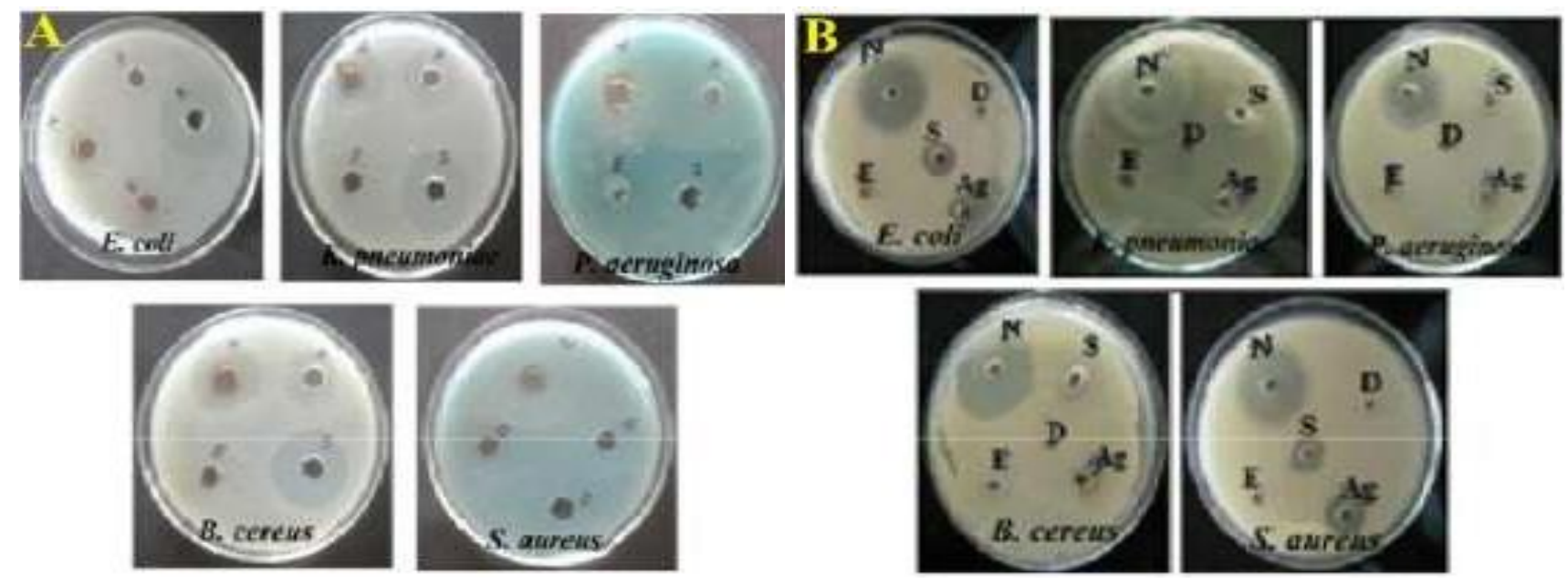

Fig. 7. Antimicrobial activity of Carissa carandas (A) and Nerium indicum (B) leaves AgNPs effects on different bacterial pathogens. 


\section{Advanced Materials Letters www.vbripress.com/aml}

\section{Antifungal activity}

The aqueous AgNPs of Carissa carandas (A) has shown antifungal activity on Candida albicans (12.967) > Aspergillus niger (12.267). The antifungal activity of Nerium indicum (B) aqueous extracts AgNPs showed the antifungal activity on Aspergillus niger (12.467) > Candida albicans (12.300). Silver NPs exhibit high antifungal activity against selected pathogenic fungi at very low concentrations of $1 \mathrm{mg} / \mathrm{ml}$ from standard drug Fluconazole. The AgNPs shown the best results compared with standard in Fig. 8(a)(b) and Table 2. The synthesized Ag nanoparticles showed the membrane damage in the Candida albicans because of destabilizing fungal intercellular components $[\mathbf{3 0 , 3 1}]$ and thus disrupting the membrane potential [32].
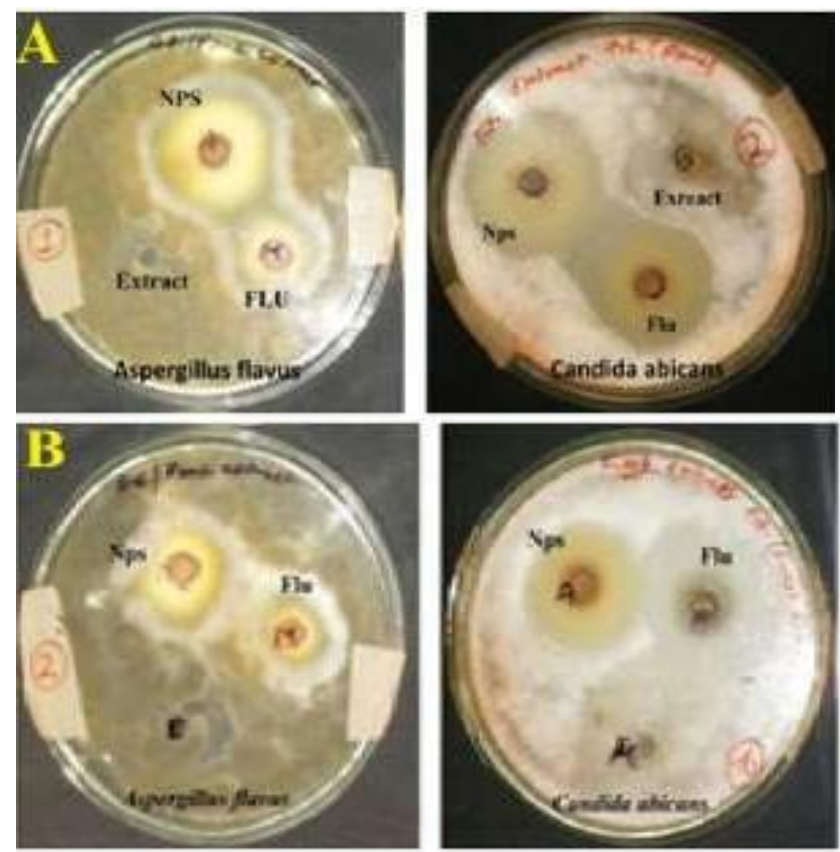

Fig. 8. Images of Carissa carandas (A) and Nerium indicum (B) AgNPs effect on antifungal strains.

Table. 2. Antifungal activity zone inhibition of Carissa carandas and Nerium indicum leaf aqueous extract AgNPs effect on Aspergillus niger and Candida albicans.

\begin{tabular}{|c|c|c|c|c|c|}
\hline \multirow{2}{*}{$\begin{array}{l}\text { Micro } \\
\text { organisms }\end{array}$} & \multirow{2}{*}{ Standard } & \multicolumn{2}{|c|}{ Carissa carandas } & \multicolumn{2}{|c|}{ Nerium indicum } \\
\hline & & NPs & Extract & NPs & Extract \\
\hline $\begin{array}{l}\text { Aspergillus } \\
\text { niger }\end{array}$ & $\begin{array}{c}14.500 \pm \\
0.200\end{array}$ & $\begin{array}{c}12.267 \pm 0.252 \\
b\end{array}$ & 0 & $\begin{array}{c}12.467 \pm 0.153 \\
\mathrm{a}\end{array}$ & 0 \\
\hline $\begin{array}{l}\text { Candida } \\
\text { albicans }\end{array}$ & $\begin{array}{c}13.40 \pm \\
0.100\end{array}$ & $\begin{array}{c}12.967 \pm 1.242 \\
\mathrm{a}\end{array}$ & 0 & $\begin{array}{c}12.300 \pm 0.200 \\
b\end{array}$ & 0 \\
\hline
\end{tabular}

\section{Anticancer activity}

The AgNPs of aqueous extract of CC and NI anticancer activity results shown in Fig. 9 (VSD \& NSD). For MCF7 cell line inhibition observed a decreasing trend as examined with CC and NI. Among these NPs CC aqueous extract AgNPs were more found more effective than NI AgNPs. SRB assay shown the minimum inhibitory concentration (IC50) of AgNPs on MCF-7 cells was obtained the incubation for 24 hours. It displays when the concentration of AgNPs increased the cytotoxicity also increased which represents the cytotoxicity depend upon on the dose against MCF-7 cancer cells $[33,34]$. AgNPs dispersed in deionized water have no notable cytotoxicity at lower concentration on MCF-7 cell lines. The results represent cytotoxic effects of these synthesized AgNPs from Carissa carandas extract on cancer cell line. The inhibition power of the AgNPs were more effective due to the particles shape, size and surface area that influence the cytotoxicity of AgNPs and important in their biological phytochemicals efficacy $[35,36]$.
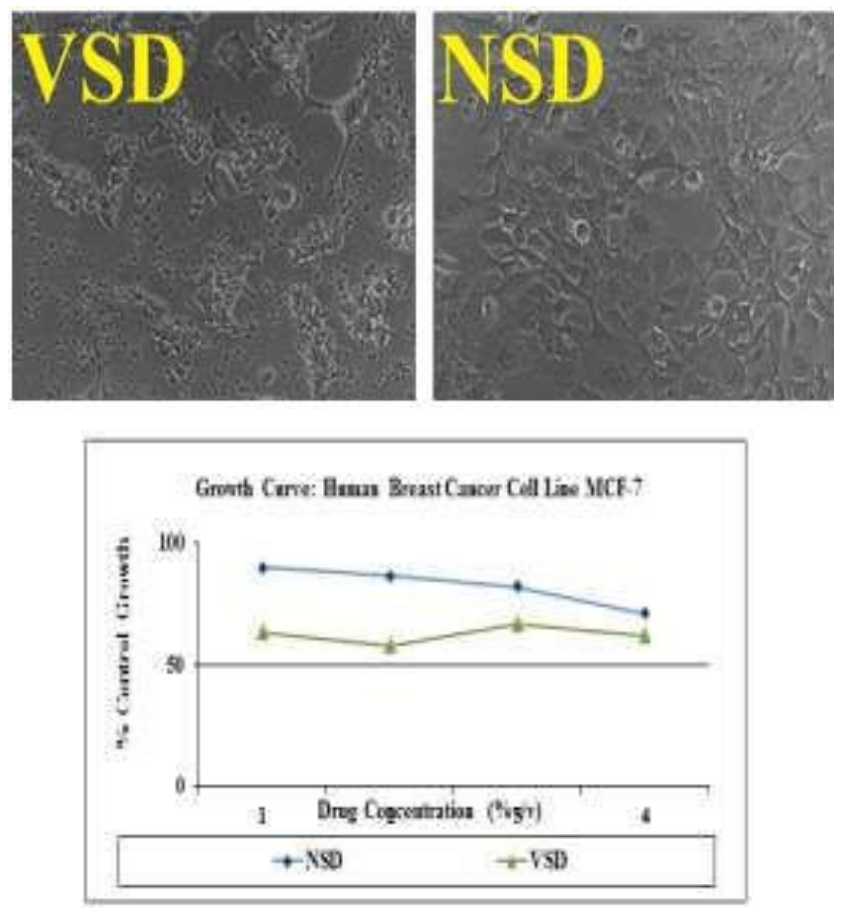

Fig. 9. Activity of Carissa carandas (VSD) and Nerium indicum (NSD) AgNPs effects on the anticancer MCF-7 cell line.

\section{Conclusion}

This work reporting that Carissa carandas and Nerium indicum plants both being having medicinal and Ayurvedic properties, the leaves extracts were used for the synthesis of AgNPs. The nanoparticles produced are ecofriendly, mono-dispersed, naturally renewable and cost effective. These AgNPs were characterized by UVVisible spectrophotometry, FTIR, SEM-EDAX and TEM analysis. The FTIR spectrum confirmed the functional groups present in nanoparticles. The color change indicates the AgNPs which is confirmed by UV-visible spectroscopy. The synthesized AgNPs were stable and in spherical, diamond and circular shapes with $20 \mathrm{~nm}$ size by SEM and TEM analysis. The microbial and cell culture results showed strong antibacterial activity against selected human pathogens and significant antifungal activity on Aspergillus flavus and Candida albicans. The synthesized silver nanoparticles were found to be effective even at low concentration against MCF-7 cells. 


\section{Advanced Materials Letters www.vbripress.com/aml}

\section{Acknowledgement}

We thankful to the Aligarh Muslim University for their support in carrying out in this research work regarding SEM-EDAX, and TEM analysis and thanks to Banaras Hindu University for their help of FT-IR spectrum analysis.

\section{Ethical statement}

There is no conflict of interest between the co-authors.

\section{Keywords}

Biosynthesis, medicinal applications, carissa carandas, nerium indicum, AgNPs.

\section{Received: 25 April 2020}

Revised: 04 July 2020

Accepted: 17 July 2020

\section{References}

1. Mukherjee, P.; Ahmad, A.; Mandal, D.; Senapati, S.; Sainkar, S.R.; Khan, M.I.; Parishcha, R.; Ajaykumar, P. V.; Alam, M.; Kumar, R.; Sastry, M.: Nano Lett., 2001, 1, 515.

2. Krishnaraj, C.; Jagan, E.G.; Rajasekar, S.; Selvakumar, P.; Kalaichelvan, P.T.; Mohan, N.: Colloids Surfaces B Biointerfaces, 2010, 76, 50.

3. Dankovich, T.A.; Gray, D.G.: Environ. Sci. Technol., 2011, 45, 1992.

4. Sastry, M.; Ahmad, A.; Islam Khan, M.; Kumar, R.: Curr. Sci., 2003, 85,162

5. Rai, A.; Singh, A.; Ahmad, A.; Sastry, M.: Langmuir, 2006, 22, 736.

6. Meenal, K.; Shriwas, A.; Sharmin, K.; W, V., J, U., SK, K., KM, P.: Extracellular Synthesis of Silver. 95.

7. Virkutyte, J.; Varma, R.S.: Chem. Sci., 2011, 2, 837.

8. Mulvihill, M.J.; Beach, E.S.; Zimmerman, J.B.; Anastas, P.T.: Annu. Rev. Environ. Resour., 2011, 36, 271.

9. Mandal, D.; Bolander, M.E.; Mukhopadhyay, D.; Sarkar, G.; Mukherjee, P.: Appl. Microbiol. Biotechnol., 2006, 69, 485.

10. Xie, J.; Lee, J.Y.; Wang, D.I.C.; Ting, Y.P.: ACS Nano., 2007, 1, 429.

11. Ahmad, N.; Sharma, S.; Alam, M.K.; Singh, V.N.; Shamsi, S.F.; Mehta, B.R.; Fatma, A.; Colloids Surfaces B Biointerfaces, 2010, 81,81 .

12. Bar, H.; Bhui, D.K.; Sahoo, G.P.; Sarkar, P.; Pyne, S.; Misra, A.; Colloids Surfaces A Physicochem. Eng. Asp., 2009, 348, 212.

13. Iravani, S.; Green Chem., 2011, 13, 2638.

14. Darroudi, M.; Ahmad, M. Bin, Abdullah, A.H.; Ibrahim, N.A.; Shameli, K.; Int. J. Mol. Sci., 2010, 11, 3898.

15. MubarakAli, D.; Thajuddin, N.; Jeganathan, K.; Gunasekaran, M.; Colloids SurfacesB Biointerfaces, 2011, 85, 360.

16. Sathishkumar, M.; Sneha, K.; Won, S.W.; Cho, C.W.; Kim, S.; Yun, Y.S.; Colloids Surfaces B Biointerfaces, 2009, 73, 332.

17. Nabikhan, A.; Kandasamy, K.; Raj, A.; Alikunhi, N.M.; Colloids Surfaces B Biointerfaces, 2010, 79, 488.

18. Prathna, T.C.; Chandrasekaran, N.; Raichur, A.M.; Mukherjee, A.; Colloids Surfaces B Biointerfaces, 2011, 82, 152.

19. Bankar, A.; Joshi, B.; Kumar, A.R.; Zinjarde, S.; Surfaces A Physicochem. Eng. Asp., 2010, 368, 58.

20. Shan, B.; Cai, Y.Z.; Sun, M.; Corke, H.; J. Agric. Food Chem., 2005, 53, 7749.

21. López, P.; Sánchez, C.; Batlle, R.; Nerín, C.; J. Agric. Food Chem. 2005, 53, 6939.

22. Kannan, N.; Mukunthan, K.S.; Balaji, S.: Colloids Surfaces B Biointerfaces, 2011, 86, 378.

23. Subba Rao, Y.; Kotakadi, V.S.; Prasad, T.N.V.K.V.; Reddy, A. V.; Sai Gopal, D.V.R.; Spectrochim. Acta - Part A Mol. Biomol. Spectrosc., 2013, 103, 156.

24. Nabikhan, A.; Kandasamy, K.; Raj, A.; Alikunhi, N.M.; Colloids and Surfaces B: Biointerfaces, 2010, 79, 488.

25. Jaidev, L.R.; Narasimha, G.; Colloids Surfaces B Biointerfaces, 2010, 81,430 .
26. Sukirtha, R.; Priyanka, K.M.; Antony, J.J.; Kamalakkannan, S.; Thangam, R.; Gunasekaran, P.; Krishnan, M.; Achiraman, S.; Process Biochem., 2012, 47, 273.

27. Kotakadi, V.S.; Gaddam, S.A.; Subba Rao, Y.; Prasad, T.N.V.K.V.; Varada Reddy, A.; Sai Gopal, D.V.R.; Eur. J. Med. Chem., 2014, 73, 135.

28. Kumar, P.; Govindaraju, M.; Senthamilselvi, S.; Premkumar, K.; Colloids Surfaces B Biointerfaces, 2013, 103, 658.

29. Malapermal, V.; Botha, I.; Krishna, S.B.N.; Mbatha, J.N.; Saudi J. Biol.Sci., 2017, 24, 1294.

30. Magudapathy, P.; Gangopadhyay, P.; Panigrahi, B.K.; Nair, K.G.M.; Dhara, S.; Phys. B Condens. Matter., 2001, 299, 142.

31. Shankar, S.S.; Rai, A.; Ankamwar, B.; Singh, A.; Ahmad, A.; Sastry, M.; Nat. Mater., 2004, 3, 482.

32. Kalishwaralal, K.; Deepak, V.; Ramkumarpandian, S.; Nellaiah, H.; Sangiliyandi, G.; Mater. Lett., 2008, 62, 4411.

33. Ganesh Babu, M.M.; Gunasekaran, P.; Colloids Surfaces B Biointerfaces, 2009, 74, 191.

34. Vijayakumar, M.; Priya, K.; Nancy, F.T.; Noorlidah, A.; Ahmed, A.B.A.; Ind. Crops Prod., 2013, 41, 235.

35. Carlson, C.; Hussein, S.M.; Schrand, A.M.; Braydich-Stolle, L.K.; Hess, K.L.; Jones, R.L.; Schlager, J.J.; J. Phys. Chem. B., 2008, 112,13608

36. Prasad, S.; Nanotechnology in Medicine and Antibacterial Effect of. 2008, 3, 115-122.

37. Horta-Piñeres, S.; Hurtado, R.B.; Avila-Padilla, D.; CortezValadez, M.; Flores-López, N.S.; Flores-Acosta, M.; Applied Physics A, 2020, 126, 15.

38. Kamranifar, M.; Allahresani, A.; Naghizadeh, A.; Journal of Hazardous Materials, 2019, 366, 545.

39. Behravan, M.; Panahi, A.H.; Naghizadeh, A.; Ziaee, M.; Mahdavi, R.; Mirzapour, A.; International Journal of Biological Macromolecules, 2019, 124, 148. 